\title{
The neuroprotective effect of picroside II via regulating the expression of myelin basic protein after cerebral ischemia injury in rats
}

\author{
Li Zhao, Yunliang Guo*, Xiaojun Ji and Meizeng Zhang
}

\begin{abstract}
Background: To explore the neuroprotective effect and optimize the therapeutic dose and time window of picroside II by orthogonal test and the expression of myelin basic protein (MBP) in cerebral ischemic injury in rats. Bilateral common carotid artery occlusion (BCCAO) was used to establish forebrain ischemia models. The successful rat models were grouped according to orthogonal experimental design and injected picroside II intraperitoneally at different ischemic time with different doses. Myelin sheath fast green staining(FGS) and transmission electron microscopy (TEM) were used to observe nerve fiber myelin; the expression of MBP was tested qualitatively and quantitatively by immunohistochemical assay (IHC) and Western blot (WB); Reverse transcription polymerase chain reaction (RT-PCR) was used to detect the transcription level of MBP mRNA.
\end{abstract}

Results: The protective effect of picroside II was presented by increasing the expression of MBP and decreasing demyelination after cerebral ischemic injury. The best therapeutic time window and dose was (1) ischemia $2.0 \mathrm{~h}$ with picroside $\| 10 \mathrm{mg} / \mathrm{kg}$ body weight according to the results of FGS, IHC and WB; (2) ischemia $1.5 \mathrm{~h}$ with picroside II $20 \mathrm{mg} / \mathrm{kg}$ according to the analysis of RT-PCR.

Conclusion: Given the principle of the longest time window and the lowest therapeutic dose, the optimized therapeutic dose and time window should be injecting picroside II intraperitoneally with $10-20 \mathrm{mg} / \mathrm{kg}$ body weight at ischemia 1.5-2.0 $\mathrm{h}$ in cerebral ischemic injury.

Keywords: Picroside II, Therapeutic dose, Time window, Cerebral ischemia, MBP, Rats

\section{Background}

As an important myelin sheath structural protein in central nervous system (CNS)[1], myelin basic protein (MBP) lies in the serous surface of myelin sheath and closely integrates with the lipids of myelin and beneficial to steady the structure and function of myelin in CNS [2]. MBP has the specificity of nervous tissues [3], MBP lossing will lead to myelination obstacles and its level can reflect the severity of the damage of CNS and myelin [4], so that sufficient $\mathrm{MBP}$ is important for the function recovery of the CNS [5]. Animal experiments [6] proved that there was a small amount expression of MBP mRNA in the brain of normal adult rats, while the MBP mRNA [7] and protein [8] decreased time-dependently in early stage of cerebral

\footnotetext{
* Correspondence: quogdsd@163.com

Institute of Cerebrovascular Diseases, Affiliated Hospital of Qingdao University, Qingdao, Shandong 266003, China
}

ischemic injury [9]. However, the expression of MBP mRNA will rise slightly as the ischemic time extension, and its expressing level at ischemia $7 \mathrm{~d}$ was significantly higher than that at ischemia 1d. Previous study reported that acupuncture treatment could increase MBP expression and promote the regeneration of myelin [10]. Picroside II, an active ingredient of traditional Chinese medicine, has many neuroprotective effects of antioxidant, anti-inflammatory, anti-apoptosis [11,12], however, whether it could influence the expression levels of MBP or not has not been reported so far. Recently, we explored the treatment dose and time window of picroside II after cerebral ischemia reperfusion injury via the neurobehavioral function of rats, cerebral infarction volume and immunohistochemical staining and proved that injecting picroside II $20 \mathrm{mg} / \mathrm{kg}$ body weight intraperitoneally at ischemia $1.5 \mathrm{~h}$ could achieved a ideal therapeutic outcome for cerebral ischemic injury in rats $[13,14]$. In consideration of the 
limitation of neurobehavioral evaluation and immunohistochemical assay, we attempted to detect the expression levels of MBP in brain tissue qualitatively and quantitatively and observe the change of myelin structure through a various biological techniques, just to explore the optimal therapeutic dose and time window of picroside II after cerebral ischemic injury.

\section{Results}

\section{Test results}

In control group, myelin showed cord-like, dark green, closely arranged after fast green staining. After modeling, myelin showed loose and light-stained, glial cell vacuolated, and myelin gray value (MGV), gray value of myelin $(\mathrm{GVM})$, relative content of protein (RCP), relative abundance of mRNA (RAM) were lower markedly than those in control group $(t=13.79-26.13, P<0.05)$. While MGV, GVM, RCP and RAM were significantly higher than those in model group after treated by picroside II $(t=3.09-3.71$, $P<0.05$ )( Table 1, Figures 1, 2, 3 and 4). The orthogonal test results were shown in Table 2. Data listed in the Table 2 are the mean of three times of orthogonal experiment. Data of I, II, II, IV and SS were the ANOVA results of $\mathrm{MGV}$, and the ANOVA results of rest indexes were omitted.

\section{Results analysis}

Myelin gray value (MGV) (Figure 1): The effects of different levels of variable factor A (time) on the injury of myelin showed a significant difference $(P<0.01)$, while no significant influence found among factor $\mathrm{B}$ (dose) and factor $C$ (time-dose interaction) $(P>0.05)$. That is to say the administration time had significant impact on the degree of myelin damage after cerebral ischemia, but the influence of administration dose and time-dose interaction was negligible (Table 3). The pairwise comparisons of data at different levels according to LSD showed that the administration time between the groups were statistically significant $(P<0.05)$. The administration dose between $5 \mathrm{mg}(\mathrm{B} 1)$ and $10 \mathrm{mg}(\mathrm{B} 2)$ was statistically significant $(P<0.05)$, while the rest groups were of no statistical significance $(P>0.05)$. From the principle of lowest therapeutic dose with longest time window, the optimized composition were A3B2, that is to say the best therapeutic dose and time window was ischemia $2.0 \mathrm{~h}$ with picroside II $10 \mathrm{mg} / \mathrm{kg}$ body weight by intraperitoneally injection.

\section{Gray value of myelin (GVM)}

(Figure 1): There was a significant difference between the different levels of impact factors A (time window or ischemic time) on the expression of myelin $(P<0.05)$, while no significant probability $(P>0.05)$ found among impact factor $B$ (drug dose) and factor $C$ (time-dose interaction). This indicated the therapeutic time window (or ischemic time) had significantly influence on the expression of myelin after cerebral ischemia injury, while no significant influence existed in different drug doses and time-dose interactions (Table 4). LSD showed that different administration time between $1.0 \mathrm{~h}(\mathrm{~A} 1)$ and $1.5 \mathrm{~h}(\mathrm{~A} 2), 1.0 \mathrm{~h}(\mathrm{~A} 1)$ and $2.0 \mathrm{~h}(\mathrm{~A} 3), 1.5 \mathrm{~h}(\mathrm{~A} 2)$ and $2.0 \mathrm{~h}$ (A3), $1.5 \mathrm{~h}(\mathrm{~A} 2)$ and $2.5 \mathrm{~h}(\mathrm{~A} 4), 2.0 \mathrm{~h}(\mathrm{~A} 3)$ and $2.5 \mathrm{~h}(\mathrm{~A} 4)$ had significant differences $(P<0.05)$, no significant differences found between the rest groups $(P>0.05)$. There was no statistical significance $(P>0.05)$ between groups on dose. So, the best combination is A3B2 $(2.0 \mathrm{~h} / 10 \mathrm{mg})$, that is injecting picroside II $10 \mathrm{mg} / \mathrm{kg}$ body weight at cerebral ischemia $2.0 \mathrm{~h}$.

Ultrastructure of myelin by TEM: In control group, the structure of myelin sheath was distinct and neat, and the neural axon was in focus; while unclear and irregular and the neural axon disappeared in model group; and the damaged myelin sheath in treatment group recovered significantly comparing with model group (Figure 2).

Relative content of protein (RCP) by WB: Quantitative detection of the expression of MBP showed that different intensity of MBP protein expressed in different groups (Figure 3), and it was significantly higher than that in model group after treatment. Analysis of variance showed that the different levels of factor A (time) had significant differences on the expression of MBP $(P<0.05)$, but no significant differences in factor $\mathrm{B}$ (dose) and factor C (time-dose interaction) (Table 5). LSD indicated that significant deviations $(P<0.05)$ were found between $1.0 \mathrm{~h}$ (A1) and $1.5 \mathrm{~h}(\mathrm{~A} 2), 1.0 \mathrm{~h}(\mathrm{~A} 1)$ and $2.0 \mathrm{~h}(\mathrm{~A} 3), 1.5 \mathrm{~h}(\mathrm{~A} 2)$ and $2.5 \mathrm{~h}(\mathrm{~A} 4), 2.0 \mathrm{~h}(\mathrm{~A} 3)$ and $2.5 \mathrm{~h}(\mathrm{~A} 4)$ in therapeutic time window, but no significant deviations between the rest therapeutic time levels $(P>0.05)$. The different therapeutic dose levels had no significant differences $(P>0.05)$. Synthetically, the best combination is A3B2 (1.5 h/10 mg), i.e. the best therapeutic time window and dose of picroside II should be injecting intraperitoneally with $10 \mathrm{mg} / \mathrm{kg}$ body weight at cerebral ischemia $2.0 \mathrm{~h}$.

Table 1 The results of MGV, GVM, RCP and RAM (mean \pm SD)

\begin{tabular}{llllll}
\hline Groups & $\mathbf{n}$ & MGV & GVM & RCP & RAM \\
\hline Control & 5 & $421.674 \pm 30.782$ & $219.591 \pm 17.693$ & $0.801 \pm 0.074$ & $1.201 \pm 0.099$ \\
Model & 5 & $273.633 \pm 17.421^{\#}$ & $127.102 \pm 6.350^{\#}$ & $0.286 \pm 0.026^{\#}$ & $0.427 \pm 0.057^{\#}$ \\
Treatment & $16 \times 3$ & $349.043 \pm 46.820^{*}$ & $166.263 \pm 12.969^{*}$ & $0.612 \pm 0.043^{*}$ & $0.662 \pm 0.154^{*}$ \\
\hline
\end{tabular}

${ }^{\#} P<0.05$ vs control group, ${ }^{*} P<0.05$ vs model group. 

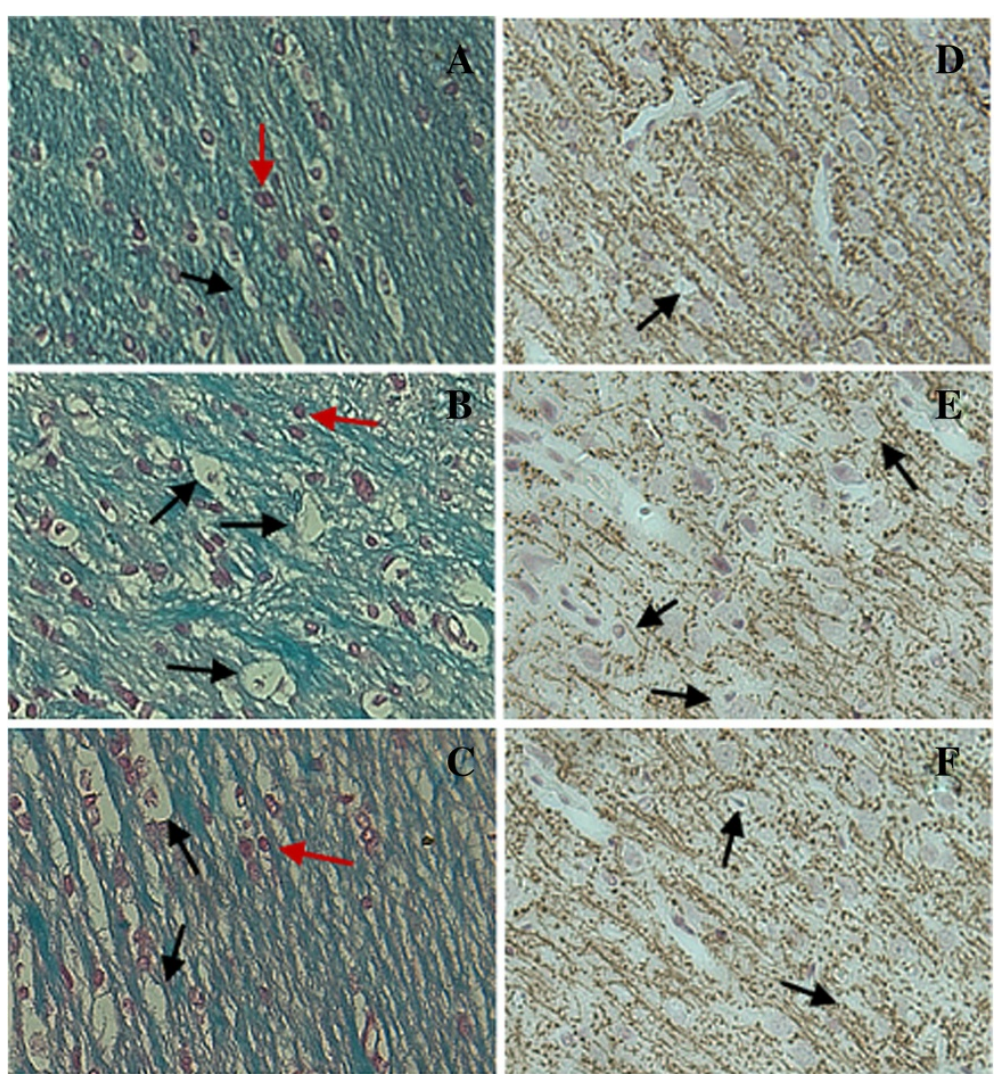

A,D:control group $B, E$ :model group $C, F$ :treatment group
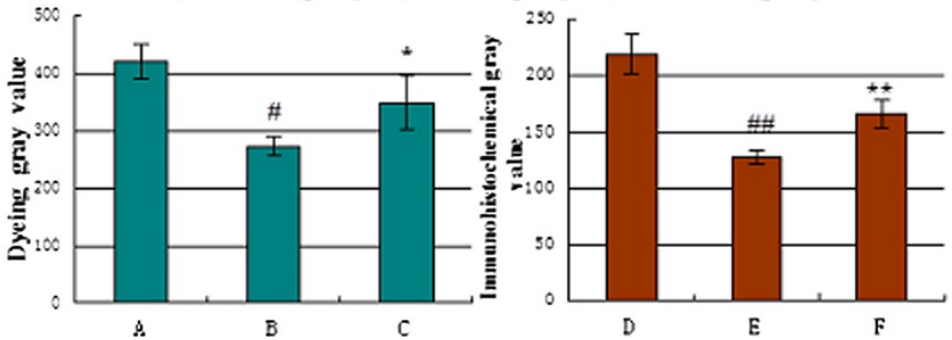

Figure 1 Myelin nerve fibers in parietal white matter of rats, FGS $\times$ 400. Normal myelin (A) showed cord-like, dark green, tightly packed, and cells was red (Red arrow); it showed myelin fibers loose and light-stained, glial cell vacuolation (Black arrow) after modeling (B). In model group, myelin gray value (MGV) decreased significantly than that in control group ( ${ }^{P} P<0.05$ vs control group) and increased significantly than that in model group after treatment (C) $\left({ }^{*} P<0.05\right.$ vs model group). The expression of MBP in parietal white matter, SABC $\times 400$. In the control group (D), myelin fibers was arranged closely and tidy. After modeling (E), myelin degeneration release and disordered, positive cells showed cytoplasmic uneven coloring, and vesicular (Black arrow). The MBP expressed significantly lower in model group (\#\# $P<0.05$ vs control group) and increased significantly and myelin fibers tightly packed in treatment group (F) (**P $<0.05$ vs model group).

Relative abundance of mRNA (RAM) by RT-PCR: The expressions of MBP mRNA differed between various groups, and increased markedly than that in model group after treatment (Figure 3). The results of ANOVA showed there was statistically difference in different levels of factor A (time) on MBP mRNA $(P<0.05)$, and no significant difference $(P>0.05)$ found in factor $B$ (dose) and factor $\mathrm{C}$ (time-dose interaction) (Table 6). LSD showed that a statistically significance $(P<0.05)$ between therapeutic time $1.0 \mathrm{~h}$ (A1) and $1.5 \mathrm{~h}$ (A2), $1.0 \mathrm{~h}$ (A1) and $2.0 \mathrm{~h}$ (A3), $1.5 \mathrm{~h}$ (A2) and $2.0 \mathrm{~h}$ (A3),
$1.5 \mathrm{~h} \mathrm{(A2)}$ and $2.5 \mathrm{~h}(\mathrm{~A} 4), 2.0 \mathrm{~h}(\mathrm{~A} 3)$ and $2.5 \mathrm{~h}$ (A4), but no statistical difference in the rest levels $(P>0.05)$ as well as the therapeutic dose levels $(P>0.05)$. Consideration of A2B3 combination is the best, so the best treatment time window and dose is $1.5 \mathrm{~h}, 20 \mathrm{mg} / \mathrm{kg}$.

\section{Discussion}

Orthogonal array is an efficient and economical test, which has the advantage of balancing samples and reducing the test times at the same time, so that each test has a strong representation [15]. In this study, we applied the 


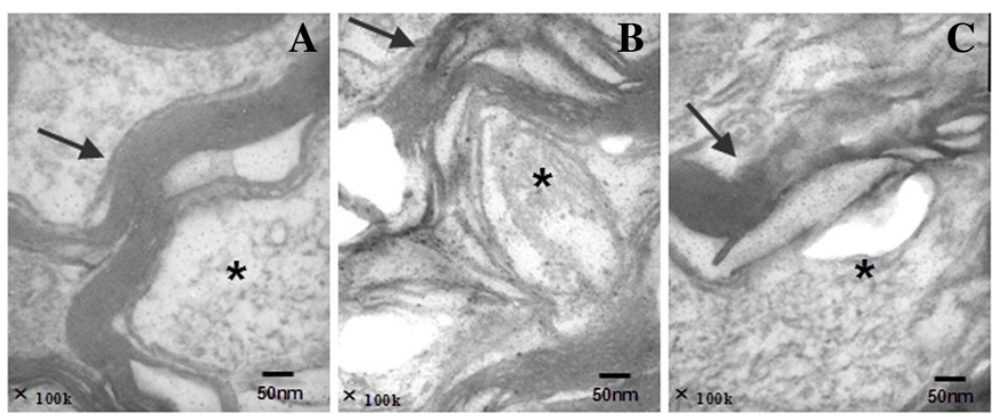

Figure 2 Ultrastructure of myelin nerve fibers in ischemic cortical area of rats, TEM. C: control group; M: model group; T: treatment group. The myelin sheath (Black arrow) and the neural axon $\left(^{*}\right)$ in control group were distinct and neat $(\mathbf{A})$, and unclear or disappeared in model group (B), and those injuries was alleviated in treatment (C)

orthogonal experiment to overall design, comprehensive comparison and statistical analyse, to find better treatment options through the small number of experiments to achieve the best therapeutic effect.

Myelin basic protein (MBP), including central and peripheral MBP, has the highest content in while matter. As a kind of basic membrane proteins with no sugar and lipid, MBP is synthesized by oligodendrocytes in central nervous system [16]. Only nerve fibers with myelination can complete its conduction function, so that MBP is an important structural protein involved in the synthesis of myelin and plays an important role in nervous system, such as insulation and fast conduction in nerve fiber $[17,18]$. The transcription products of MBP gene in human and mouse are different. There are at least 5 kinds of products including $21.5 \mathrm{kD}, 18.5 \mathrm{kD}, 17 \mathrm{a}, 17 \mathrm{~b}$ and 14 $\mathrm{kD}$ in mouse brain. However, there are only 4 kinds of products consisting of $21.5 \mathrm{kD}, 20.2 \mathrm{kD}, 18.5 \mathrm{kD}$ and $17.3 \mathrm{kD}$ in human brain, of which the $18.5 \mathrm{kD} \mathrm{MBP}$ is the main protein of mature myelin in central nervous system $[19,20]$. Normally the concentration of MBP in cerebrospinal fluid (CSF) is lower than $6.95 \mathrm{mg} / \mathrm{L}$. After cerebral ischemia, the ischemia and hypoxia of brain tissue can lead to oligodendrocyte death and demyelination, so caused MBP flowing into CSF. In addition, cerebral injury can damage the structure of blood-brain barrier (BBB) and cause MBP leaked in CSF passing through $\mathrm{BBB}$ into blood. Therefore, determining the serum level of MBP could partly reflect whether there was brain injury or not, and MBP level in serum also become a specific marker protein to judge demyelination [21-23]. Previous animal experiments showed that the expression of MBP mRNA and protein reduced in the early period of cerebral ischemic injury, especially in the first $24 \mathrm{~h}$, and the content of MBP protein decreased significantly [24]. Recently, some experiments [4,25,26] reported that MBP played an important role in the prediction of the severity of brain injury and the prognosis, and the increased expression of MBP played a role in the protection of brain [27]. In this experiment, we determined the expression of MBP mRNA and protein to evaluate the degree of brain injury. The results showed that after cerebral ischemic injury, the expression of MBP mRNA and protein significantly decreased; and LFB staining and TEM showed that myelin fibers synchronous reduced and the damaged-positive cells were

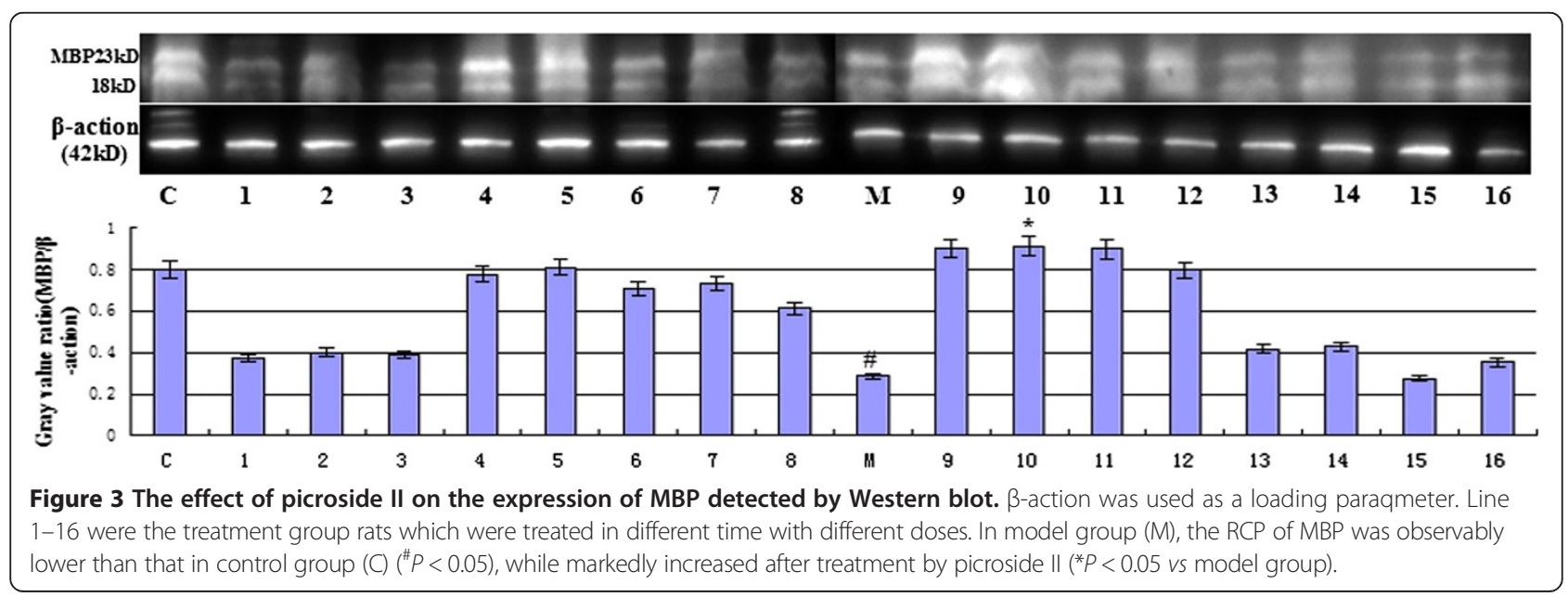




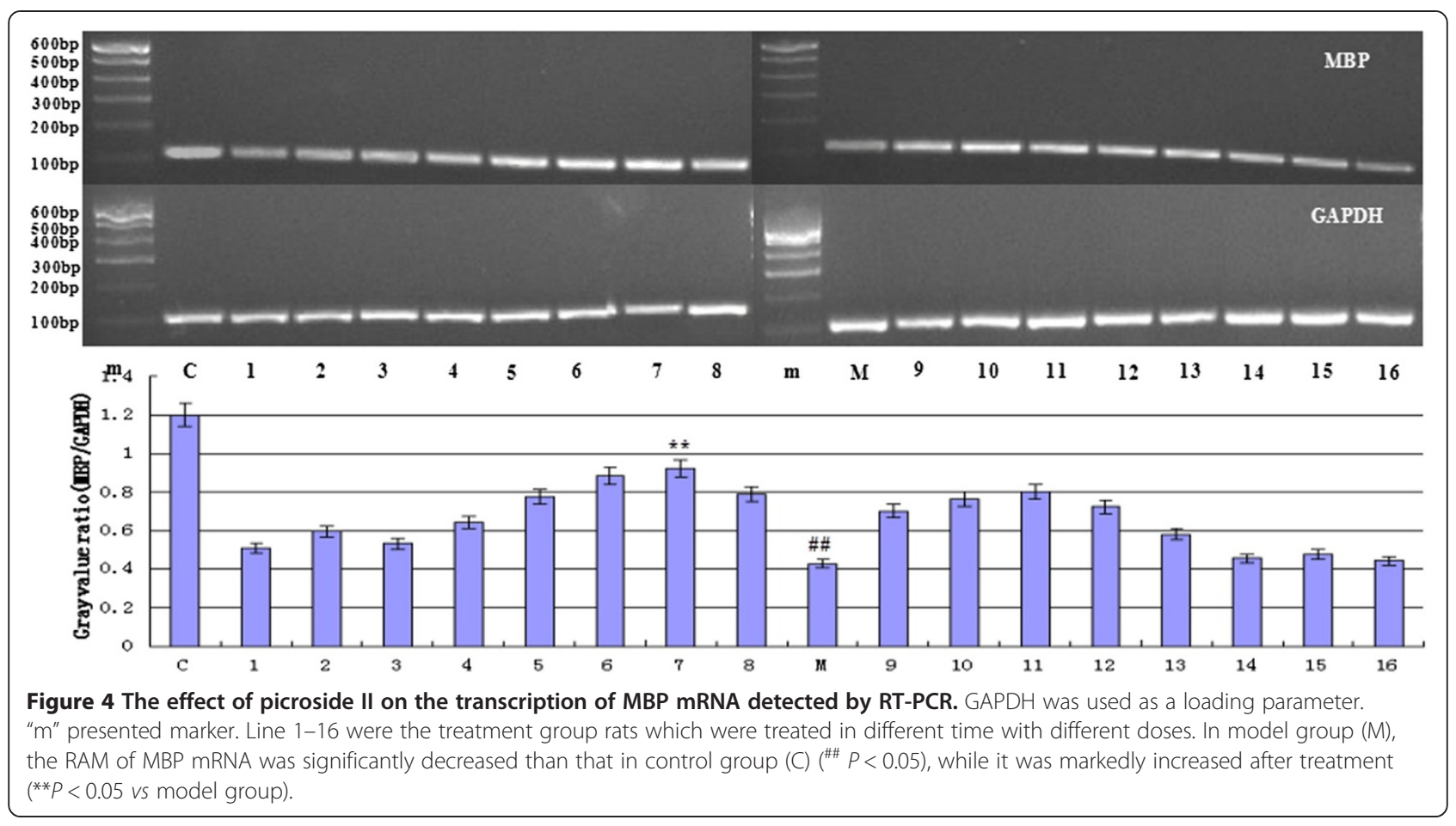

Table $2\left[\mathrm{~L}_{16}\left(4^{5}\right)\right]$ orthogonal table and test results

\begin{tabular}{|c|c|c|c|c|c|c|c|c|c|}
\hline \multirow[t]{2}{*}{ Test no. } & \multicolumn{5}{|c|}{ Rank no. } & \multirow[t]{2}{*}{ MGV } & \multirow[t]{2}{*}{ GVM } & \multirow[t]{2}{*}{$\mathrm{RCP}$} & \multirow[t]{2}{*}{ RAM } \\
\hline & $A$ & B & C & D & $E$ & & & & \\
\hline 1 & 1 & 1 & 1 & 1 & 1 & 283.654 & 127.002 & 0.373 & 0.507 \\
\hline 2 & 1 & 2 & 2 & 2 & 2 & 297.874 & 136.098 & 0.402 & 0.596 \\
\hline 3 & 1 & 3 & 3 & 3 & 3 & 290.544 & 137.056 & 0.39 & 0.531 \\
\hline 4 & 1 & 4 & 4 & 4 & 4 & 320.887 & 146.417 & 0.777 & 0.643 \\
\hline 5 & 2 & 1 & 2 & 3 & 4 & 342.117 & 158.028 & 0.812 & 0.777 \\
\hline 6 & 2 & 2 & 1 & 4 & 3 & 389.432 & 190.337 & 0.707 & 0.885 \\
\hline 7 & 2 & 3 & 4 & 1 & 2 & 396.745 & 184.114 & 0.734 & 0.923 \\
\hline 8 & 2 & 4 & 3 & 2 & 1 & 379.667 & 178.013 & 0.612 & 0.789 \\
\hline 9 & 3 & 1 & 3 & 4 & 2 & 388.798 & 189.100 & 0.901 & 0.702 \\
\hline 10 & 3 & 2 & 4 & 3 & 1 & 420.765 & 207.135 & 0.912 & 0.765 \\
\hline 11 & 3 & 3 & 1 & 2 & 4 & 400.456 & 202.007 & 0.897 & 0.801 \\
\hline 12 & 3 & 4 & 2 & 1 & 3 & 398.567 & 195.243 & 0.798 & 0.723 \\
\hline 13 & 4 & 1 & 4 & 2 & 3 & 330.734 & 161.477 & 0.417 & 0.579 \\
\hline 14 & 4 & 2 & 3 & 1 & 4 & 341.100 & 169.549 & 0.43 & 0.455 \\
\hline 15 & 4 & 3 & 2 & 4 & 1 & 310.967 & 147.608 & 0.276 & 0.476 \\
\hline 16 & 4 & 4 & 1 & 3 & 2 & 292.374 & 131.03 & 0.352 & 0.444 \\
\hline SUM & & & & & & 5584.681 & 2660.214 & 9.790 & 10.596 \\
\hline I & 1192.959 & 1345.303 & 1365.916 & 1420.066 & 1395.053 & & & & \\
\hline$\|$ & 1507.961 & 1449.171 & 1349.525 & 1408.731 & 1375.791 & & & & \\
\hline III & 1608.586 & 1398.712 & 1400.109 & 1345.800 & 1409.277 & & & & \\
\hline IV & 1275.175 & 1391.495 & 1469.131 & 1410.084 & 1404.560 & & & & \\
\hline SS & 28388.071 & 1356.219 & 2107.471 & 864.883 & 164.684 & & & & \\
\hline
\end{tabular}


Table 3 ANOVA of MGV

\begin{tabular}{llllll}
\hline Source of variation & SS & Df & MS & $\boldsymbol{F}$ & $\boldsymbol{P}$ \\
\hline Time window & 28388.071 & 3 & 9462.690 & 55.15 & 0.01 \\
Drug dose & 1356.219 & 3 & 452.073 & 2.64 & 0.14 \\
Time $\times$ dose & 2107.471 & 3 & 702.490 & 4.09 & 0.07 \\
Error & 1029.568 & 6 & 171.595 & & \\
\hline
\end{tabular}

significantly increased, thus confirming that the detection of MBP at all levels can be a biological indicator of brain injury and demyelination.

Picroside II is an active ingredient of Picrorhizae, which pharmacological functions consist of cleaning heat, drying humidity, alleviating fever, eliminating dampness, retreating steam, cooling blood and cholagogue [28]. Li et al. [29] confirmed that picroside II had antioxidant effect and could reduce the $\mathrm{H}_{2} \mathrm{O}_{2}$-induced injury in PC12 cells to improve the cell survival [30]. Our research team found that picroside II could inhibit the expression of inflammatory factors such as Toll-like receptor 4 (TLR4), nuclear factor $\kappa \mathrm{B}(\mathrm{NF} \kappa \mathrm{B})$, caspase enzymes-3 (caspase-3), and tumor necrosis factor $\alpha$ (TNF $\alpha)$ in cerebral ischemic penumbra after middle cerebral artery occlusion and reperfusion, and then inhibit neuronal apoptosis induced by ischemia [31-35]. This experiment results showed that comparing with the model group, the myelin nerve fibers arranged in order, vacuolar cells decreased, the expression of MBP and the transcription levels of MBP mRNA increased on different degrees after treatment by picroside II. These results proved the neuroprotective effect of picroside II against cerebral ischemic injury from various aspects and levels. Further time window and therapeutic dose optimization showed that injecting picroside II $10-20 \mathrm{mg} / \mathrm{kg}$ body weight intraperitoneally at ischemia $1.5 \mathrm{~h}-2.0 \mathrm{~h}$ could be achieved a significant effect against cerebral ischemic injury.

\section{Conclusion}

Given the principle of lowest therapeutic dose with longest time window, the optimized therapeutic dose and time window should be injecting picroside II intraperitoneally with $10-20 \mathrm{mg} / \mathrm{kg}$ body weight at ischemia 1.5 $2.0 \mathrm{~h}$ in cerebral ischemic injury in rats.

Table 4 ANOVA of GVM

\begin{tabular}{llllll}
\hline Source of variation & SS & Df & MS & $\boldsymbol{F}$ & $\boldsymbol{P}$ \\
\hline Time window & 8916.233 & 3 & 2972.078 & 28.77 & 0.01 \\
Drug dose & 638.716 & 3 & 212.905 & 2.06 & 0.21 \\
Time $\times$ dose & 560.222 & 3 & 186.741 & 1.81 & 0.25 \\
Error & 619.788 & 6 & 103.298 & & \\
\hline
\end{tabular}

Table 5 ANOVA of RCP

\begin{tabular}{llllll}
\hline Source of variation & SS & Df & MS & $\boldsymbol{F}$ & $\boldsymbol{P}$ \\
\hline Time window & 0.625 & 3 & 0.208 & 12.84 & 0.01 \\
Drug dose & 0.009 & 3 & 0.003 & 0.18 & 0.91 \\
Time $\times$ dose & 0.052 & 3 & 0.017 & 1.06 & 0.43 \\
Error & 0.097 & 6 & 0.016 & & \\
\hline
\end{tabular}

\section{Methods}

Establishment of animal models and grouping

Total of 200 adult healthy male Wistar rats (weighted 230-250 g, SPF grade) were supplied by the Experiment Animal Center of Qingdao Drug Inspection Institute (SCXK (LU) 20100100). This experiment was approved by the Ethics Committee of Qingdao University Medical College (QUMC 2011-09). The local legislation for ethics of experiment on animals and guidelines for the care and use of laboratory animals were followed in all animal procedures. All animals were acclimatized for $7 \mathrm{~d}$ humidity-controlled housing with natural illumination and allowed to eat and drink freely at room temperature $\left(23 \pm 2^{\circ} \mathrm{C}\right)$. Fifteen $(5 \times 3)$ rats were randomly selected for control group, and the rest 185 rats were anesthetized by injecting intraperitoneally $10 \%$ chloral hydrate $(3 \mathrm{ml} / \mathrm{kg}$ ) after fasting for $12 \mathrm{~h}$ and fixed in supine position to conduct aseptic operation strictly. The bilateral common carotid arteries were colligated to establish forebrain ischemic models (BCCAO) [36,37]. The rats of control group $(5 \times 3)$ were operated as the same experimental procedures besides BCCAO. Core body temperature was keeping with a rectal probe and maintained at $36-37^{\circ} \mathrm{C}$ using a homeothermic blanket control unit during and after the surgery operation. Twenty-six rats un-awakened or died after $2 \mathrm{~h}$ of operation were rejected out, while 159 successful models whose cerebral blood flow curve (PeriFlux 5000, Sweden) dropped to 30\% were brought into the experiment and were randomly divided into model group $(5 \times 3$ cases $)$ and treatment group $(16 \times 3 \times 3$ case $)$.

\section{Orthogonal experimental design and intervention}

The treatment group rats $(16 \times 3 \times 3$ case $)$ were subgrouped according to the principle of orthogonal experimental design of $\left[L_{16}\left(4^{5}\right)\right]$ consisting of two impact factors with four impact levels. The impact factor A is the therapeutic time widow designed four levels as $1.0 \mathrm{~h}, 1.5 \mathrm{~h}$,

Table 6 ANOVA of RAM

\begin{tabular}{llllll}
\hline Source of variation & SS & Df & MS & $\boldsymbol{F}$ & $\boldsymbol{P}$ \\
\hline Time window & 0.316 & 3 & 0.105 & 46.73 & 0.01 \\
Drug dose & 0.005 & 3 & 0.002 & 0.70 & 0.59 \\
Time $\times$ dose & 0.026 & 3 & 0.009 & 3.84 & 0.08 \\
Error & 0.014 & 6 & 0.002 & & \\
\hline
\end{tabular}


$2.0 \mathrm{~h}, 2.5 \mathrm{~h}$ after ischemia. The impact factor $\mathrm{B}$ is the therapeutic drug dose which has four levels as following $5 \mathrm{mg} / \mathrm{kg}, 10 \mathrm{mg} / \mathrm{kg}, 20 \mathrm{mg} / \mathrm{kg}$ and $40 \mathrm{mg} / \mathrm{kg}$ body weight. The orthogonal experimental test was repeated 3 times.

Picroside II (CAS No: 39012-20-9) which the purity exceed $98 \%$ and molecular formula is $\mathrm{C}_{23} \mathrm{H}_{28} \mathrm{O}_{13}$, supplied by Tianjin Kuiqing Medical Technology Co. Ltd. According to the weight of rats, corresponding dose of picroside II powder was taken and diluted into $1 \mathrm{ml}$ solution by isotonic saline solution and injected intraperitoneally according to the corresponding designed doses at designed time in the orthogonal layout $\left[L_{16}\left(4^{5}\right)\right]$. Rats in control group and model group were intraperitoneally injected the same dose saline after cerebral ischemia $2 \mathrm{~h}$. The brain tissue was took out to evaluate the therapeutic effect of picroside II after treatment $24 \mathrm{~h}$.

\section{Fast green staining(FGS)}

The rats from control group (5 cases), model group (5 cases) and treatment group ( $16 \times 3$ cases) were randomly chosen and anesthetized by injecting intraperitoneally $10 \%$ chloral hydrate $(3 \mathrm{ml} / \mathrm{kg})$, and perfused by normal saline $200 \mathrm{ml}$ and fixed by $4 \%$ paraformaldehyde solution $200 \mathrm{ml}$ successively via heart. Then the whole brain was taken out and post-fixed in 4\% formaldehyde solution for $2 \mathrm{~h}$ and soaked in distilled water for $4 \mathrm{~h}$. After conventional gradient ethanol dehydration, xylene transparent, paraffin embedding, coronal sections with a thickness of $5 \mu \mathrm{m}$ were continuously cut forward from the posterior of optic chiasma by a microtome (Leica CM2027, Germany) and then adhered on the slices processed with poly-lysine.

The paraffin sections were dewaxed by dimethyl benzene and washed routinely, dyed $1 \mathrm{~h}$ in fast green alcohol solution at $37^{\circ} \mathrm{C}$ after dealing with $95 \%$ alcohol $1 \mathrm{~min}$, and then washed by $95 \%$ alcohol (10 $\mathrm{s} \times 2$ times) and distilled water ( $15 \mathrm{~s} \times 3$ times), putted in $0.3 \%$ lithium carbonate to separate color, re-stained 90 s by nuclear fast red after washing by distilled water ( $15 \mathrm{~s} \times 3$ times), finally washed by distilled water and conventionally dehydrated by gradient ethanol, cleared by xylene and sealed with neutral balsam. Normal myelin showed cord-like, dark green, tightly packed, and cells were red under light microscope. Five non-overlap visual fields at ischemic area were randomly observed under 400-fold light microscope. Quantity One software was used to analyse the gray value and took the mean. The change of myelin was presented by myelin gray value (MGV = MBP gray value - background gray value).

\section{Transmission electron microscopy (TEM)}

Ultrathin sections: Took some fresh brain tissue from the ischemic area and cut into pieces of $1 \mathrm{~mm} \times 1 \mathrm{~mm} \times$ $1 \mathrm{~mm}$, fixed with $2.5 \%$ glutaraldehyde for $24 \mathrm{~h}$ and $1 \%$ osmium tetroxide for $2 \mathrm{~h}$ and dehydrated by graded series of acetone. Then soaked with the mixture of acetone and embedding solution (1:1) for $1.5 \mathrm{~h}$ and pure embedding solution overnight at $37^{\circ} \mathrm{C}$ respectively. The samples were put into the embedding plate filled with epoxy resin Epon812 to form embedding blocks eventually. The $50 \mathrm{~nm}$ ultrathin sections were cut by the ultramicrotome (Leica EM UC6, Germany) and placed on the nets prepared with polyvinyl formal, stored at $4^{\circ} \mathrm{C}$.

TEM: Dripped a drop of 3\% uranyl acetate-alcohol saturated solution $(\mathrm{pH}=3.5)$ in a petri dish, covered the nets of ultrathin sections to contact with the dye liquor to stain for $30 \mathrm{~min}$, and rinsed with double-distilled water for $10 \mathrm{~min} \times 3$ times to suck up water. Then, covered the nets of ultrathin sections to a drop of $6 \%$ lead citrate dye liquor $(\mathrm{pH}=12)$ in another petri dish to stain for $5 \mathrm{~min}$, rinsed with non-carbon dioxide double-distilled water for $10 \mathrm{~min} \times 3$ times, dried at room temperature. The ultrastructure of myelin was observed under TEM (JEM-1200EX, Japan).

\section{Immunohistochemical (IHC) assay}

Paraffin sections prepared as above were dewaxed and washed routinely, operated by the specification of SABC kit, developed by DAB chromogenic reagent kit and restained by hematoxylin (all kits were provided by Wuhan Boster Biotech Co. Ltd). Under light microscope myelin showed claybank streak and positive cells' cytoplasm presented uneven coloring, vacuolization in cells. Negative control slices were dyed with $0.01 \mathrm{~mol} / \mathrm{L}$ PBS instead of rabbit anti-rat MBP primary antibody and no positive reaction appeared. Five non-overlap visual fields randomly at ischemic area were chose under 400-fold light microscope. The gray value was analysed by the software of Quantity One and last took the mean. The expressing intensity of MBP was presented by gray value of myelin (GVM = MBP gray value - background gray value).

\section{Western blot (WB)}

Extraction of total protein: After treatment $24 \mathrm{~h}$, we randomly chose 5 rats from control group, 5 from model group and $(16 \times 3)$ from treatment group to perfuse from heart with normal saline $200 \mathrm{ml}$ following anesthetizing by $10 \%$ chloral hydrate. Took $200 \mathrm{mg}$ ischemic brain tissue and put it into $1.5 \mathrm{ml}$ EP tubes, added cell lysis buffer as the proportion of 1:4 (No. P0013, Biyuntian Biotech Co. Ltd., China), then grinded fully and homogenized by ultrasonic wave at $-4^{\circ} \mathrm{C}$ ice bath, and collected the supernatant in another EP tube after centrifuging with $10,949 \mathrm{~g}$ for $10 \mathrm{~min}$ at $4^{\circ} \mathrm{C}$ (Eppendorf 5801, Germany). The BCA-100 protein quantitative kit (Shenneng Biotech. Co. Ltd., China) was used to determine the protein content, then stored at $-20^{\circ} \mathrm{C}$. 
Western blot: MBP proteins (18, $23 \mathrm{kD})$ were separated by sodium dodecyl sulfate polyacrylamide gel electrophoresis (12\% separating gel on $75 \mathrm{~V}$ and $5 \%$ concentrated gel on $120 \mathrm{~V}$ successively) and transferred onto a polyvinylidene difluoride membranes (40 min with $360 \mathrm{~mA}$ ). Phosphate buffered saline with Tween-10 (PBST) was used to wash the gel films 5 min by 3 times, then the films were added rabbit anti-rat MBP primary antibodies (1:450, Abcam Company, Ab40390) to incubate $2 \mathrm{~h}$ and washed by PBST for $10 \mathrm{~min}$ by 3 times, then incubated $1 \mathrm{~h}$ in horseradish peroxidase goat anti-rabbit antibodies (1:10000, Beijing Golden Bridge Biotech. Co. Ltd., ZB2301), finally washed with PBST and PBS successively for $5 \mathrm{~min}$ by 3 times. The gel film images was developed in A-B mixed developing agent and scanned with Bio-Rad-2000 gel-imaging system to analysed gray value of strap by Quantity One software. In the same specimen, the gray value of $\beta$-action (42 kD), as an internal parameter, was also detected to calibrate the content of each target protein. The relative content of protein $(\mathrm{RCP})=$ the gray value of $\mathrm{MBP} /$ the gray value $\beta$-action. The experiment was repeated 3 times and the results presented with mean \pm standard deviation.

\section{Reverse transcription polymerase chain reaction (RT-PCR)}

Extraction of total RNA: Chose 5 rats from control group and model group respectively and $(16 \times 3)$ rats in treatment group randomly and anesthetized by chloral hydrate after treatment $24 \mathrm{~h}$. Took $200 \mathrm{mg}$ ischemic brain tissue and put into $1.5 \mathrm{ml}$ EP tube. Added RNASolv reagent $1 \mathrm{ml}$, minced and grinded, oscillated ultrasonically for $30 \mathrm{~s}$ and placed $5 \mathrm{~min}$ at room temperature, and centrifuged $\left(4^{\circ} \mathrm{C} 12,000 \mathrm{~g}\right)$ for $15 \mathrm{~min}$. Took the supernatant into another EP tube and added chloroform $0.2 \mathrm{ml}$, shocked and mixed $15 \mathrm{~s}$, placed on ice for $10 \mathrm{~min}$ and centrifuged $\left(4^{\circ} \mathrm{C} 12,000 \mathrm{~g}\right)$ for $15 \mathrm{~min}$. Then, collected supernatant into another EP tube and join isopropyl alcohol $0.5 \mathrm{ml}$, blended gently, then placed on the ice for $10 \mathrm{~min}$, centrifuged $\left(4^{\circ} \mathrm{C} 12,000 \mathrm{~g}\right)$ for $15 \mathrm{~min}$ and discarded supernatant. Washed precipitation using $1 \mathrm{ml} \mathrm{75 \%}$ alcohol, mixed and centrifuged $\left(4^{\circ} \mathrm{C} 7,500 \mathrm{~g}\right)$ for $5 \mathrm{~min}$, then abandoned supernatant carefully, dried $30 \mathrm{~min}$ (precipitation changed from white to transparent) in fume hood, and put in $57^{\circ} \mathrm{C}$ water bath for 10 min after adding $0.1 \%$ DEPC $-\mathrm{H}_{2} \mathrm{O} 30 \mu \mathrm{l}$. The purity and abundance of RNA were determined by ultraviolet spectrophotometer (Bekamann DU640, USA) and stored at $-20^{\circ} \mathrm{C}$.

RT-PCR: (1) Primers were designed with Premier 5.0 software and synthesized by Shanghai Invitrogen Co. Ltd. Target gene NSE (103 bp), sense primer: 5'-CCC ATT GGT GCA CAC TAA CCT-3', antisense: 5'-CGA CTT GAT TCA GCG ACA GGA-3'; GAPDH (110 bp) as an internal parameter, sense primer: 5'-CGT TGA CAT CCG TAA AGA CCT C-3', antisense: 5'-TAG
GAG CCA GGG CAG TAA TCT-3'. (2) Reverse transcription synthesis system of cDNA $(25 \mu \mathrm{l}$ in total): Oligod T $2 \mu \mathrm{l}$ and RNA $2 \mu \mathrm{g}$ with DEPC- $\mathrm{H}_{2} \mathrm{O}$ added to 13.4 $\mu \mathrm{l}$, and the mixed liquid was placed at $70^{\circ} \mathrm{C}$ for $5 \mathrm{~min}$, then ice-bath for $5 \mathrm{~min}$. Plused M-MLV RT $5 \times$ $5 \mu \mathrm{l}$, dNTP mixture $5 \mu \mathrm{l}$, RNase inhibitor $0.62 \mu \mathrm{l}$ and M-MLV RTase $1 \mu \mathrm{l}$. Then the mixed liquid was placed at $42^{\circ} \mathrm{C}$ for $1 \mathrm{~h}$, reacted at $70^{\circ} \mathrm{C}$ for $15 \mathrm{~min}$, and finally preserved at $-20^{\circ} \mathrm{C}$. (3) PCR system $(50 \mu \mathrm{l}): 5 \mu \mathrm{l} 10 \times$ PCR buffer, $1 \mu \mathrm{l}$ dNTP $(10 \mathrm{mmol} / \mathrm{L}), 1 \mu \mathrm{l}$ cDNA, $1 \mu \mathrm{l}$ primer 1 (10 um), $1 \mu \mathrm{l}$ primer2 (10 um), $0.4 \mu \mathrm{l}$ Taq polymerase, with $0.1 \%$ DEPC- $\mathrm{H}_{2} \mathrm{O}$ added to $50 \mu \mathrm{l}$. PCR condition: The cDNA of MBP and GAPDH were amplified for 30 cycles, at $95^{\circ} \mathrm{C}$ for $3 \mathrm{~min}, 94^{\circ} \mathrm{C}$ for $30 \mathrm{~s}, 58^{\circ} \mathrm{C}$ for $30 \mathrm{~s}$, and $72^{\circ} \mathrm{C}$ for $40 \mathrm{~s}$, and finally extension at $72^{\circ} \mathrm{C}$ for $3 \mathrm{~min}$. (4) Electrophoresis: $50 \mu \mathrm{l}$ RT-PCR system with $10 \mu \mathrm{l} 6 \times$ DNA loading buffer added into, was shocked and blended, and then centrifuged for $5 \mathrm{~s}$, followed with $10 \mu \mathrm{l}$ sample loaded. Appropriate DNA Marker was selected to load $2 \mu \mathrm{l}$, and followed with $2 \%$ agarose gel electrophoresis $(120 \mathrm{~V} / 100 \mathrm{~mA})$ for $30 \mathrm{~min}$ and ethidium bromide (EB) staining. Quantity One software was used to analyse the gray value after scanning by Bio-Rad-2000 gel-imaging system. The results were presented as relative abundance of mRNA (RAM): the gray values of MBP mRNA/ GAPDH mRNA. The results were repeated 3 times and expressed with mean \pm standard deviation.

\section{Statistical analysis}

Determination of statistical significance was carried out with Student's $t$-test between two groups. One-way analysis of variance (One-way ANOVA) was used for the comparison of multiple sets of data, then further study was made by Least significant differences (LSD) to compare multiple data. All datum statistically analysed by SPSS 17.0 software. Values were considered to be significant when $P$ was less than 0.05 .

\section{Competing interests}

The authors declare that they have no competing interests.

\section{Authors' contributions}

$L Z$ and $Y G$ were designed the study protocol. LZ, XJ and MZ collected the data. LZ analyzed and interpreted the findings and wrote the manuscript. YG performed a critical revision of the manuscript for important intellectual content and was responsible for submitting the final manuscript. All authors read and approved the final manuscript.

\section{Acknowledgement}

This study was supported by grant-in-aids for the Natural Science Fund of China (81041092, 81274116).

Received: 4 September 2013 Accepted: 11 February 2014 Published: 14 February 2014

\section{References}

1. Kuboyama K, Fujikawa A, Masumura M, Suzuki R, Matsumoto M, Noda M: Protein tyrosine phosphatase receptor type $z$ negatively regulates 
oligodendrocyte differentiation and myelination. PLoS One 2012, 7(11):e48797.

2. Wunderlich MT, Wallesch CW, Goertler M: Release of neurobiochemical markers of brain damage is related to the neurovascular status on admission and the site of arterial occlusion in acute ischemic stroke. J Neurol Sci 2004, 227(1):49-53.

3. DeBruin LS, Haines JD, Wellhauser LA, Radeva G, Schonmann V, Bienzle D, Harauz G: Developmental partitioning of myelin basic protein into membrane microdomains. Neurosci Res 2005, 80(2):211-225.

4. Lamers KJ, Vos P, Verbeek MM, Rosmalen F, van Geel WJ, van Engelen BG: Protein S-100B, neuron-specific enolase (NSE), myelin basic protein (MBP) and glial fibrillary acidic protein (GFAP) in cerebrospinal fluid (CSF) and blood of neurological patients. Brain Res Bull 2003, 61(3):261-264.

5. Bedell MA, Jenkins NA, Copeland NG: Good genes in bad neighbourhoods. Nat Genet 1996, 12(3):229-232.

6. Chen $Y$, Yi Q, Liu G, Shen $X$, Xuan L, Tian Y: Cerebral white matter injury and damage to myelin sheath following whole-brain ischemia. Brain Res 2013, 1495:11-17.

7. Tian Y, Shi Z, Yang S, Chen Y, Bao S: Changes in myelin basic protein and demyelination in the rat brain within 3 months of single 2-, 10-, or 30-Gy whole-brain radiation treatments. J Neurosurg 2008, 109(5):881-888.

8. Chu M, Hu X, Lu S, Gan Y, Li P, Guo Y, Zhang J, Chen J, Gao Y: Focal cerebral ischemia activates neurovascular restorative dynamics in mouse brain. Front Biosci (Elite Ed) 2012, 4:1926-1936.

9. Chen YZ, Bao H, Tian Y, Bao SY, XU J, Yuan CL: mRNA expression change of myelin gene in hippocampus following cerebral ischemia. Chin J Emerg Med 2007, 16(9):929-932.

10. Duan JG, Liu M: The effect of acupuncture on MBP mRNA expression in ischemic stroke rats. Chin J Rehabil Med 2009, 24(3):240-251.

11. Meng FJ, Hou ZW, Li Y, Yang Y, Yu B: The protective effect of picroside II against hypoxia/ reoxygenation injury in neonatal rat cardiomyocytes. Pharm Biol 2012, 50(10):1226-1232.

12. Guo YL, Shen W, Du F, Li Q, Li Z: Effect of picroside II on expressions of TLR4 and NFKB in rats with cerebral ischemia reperfusion injury. Chin J Integr Tradit West Med 2011, 31(1):58-61.

13. Li HY, Zhao L, Su X, Pei HT, Zhang MZ, Xin H, Guo YL: The protection and optimizing for the therapeutic dose and time window of picroside II in cerebral ischemic injury in rats. Chin Pharmacol Bull 2012, 28(4):549-553.

14. Pei $H$, Su X, Zhao L, Li H, Guo Y, Zhang M, Xin H: Primary study for the therapeutic dose and time window of picroside II in treating cerebral ischemic injury in rats. Int J Mol Sci 2012, 13(3):2551-2562.

15. Liu RJ, Zhang YW, Wen CW, Tang J: Study on the design and analysis methods of orthogonal experiment. Experimental Technology and Management 2010, 27(9):52-55.

16. Boggs JM: Myelin basic protein: a multifunctional protein. Cell Mol Life Sci 2006, 63(17):1945-1961.

17. Arroyo EJ, Scherer SS: On the molecular architecture of myelinated fibers. Histochem Cell Biol 2000, 113(1):1-18.

18. Baumann N, Pham-Dinh D: Biology of oligodendrocyte and myelin in the mammalian central nervous system. Physiol Rev 2001, 81(2):871-927.

19. Harauz G, Ishiyama N, Hill CM, Bates IR, Libich DS, Farès C: Myelin basic protein-diverse conformational states of an intrinsically unstructured protein and its roles in myelin assembly and multiple sclerosis. Micron 2004, 35(7):503-542.

20. Givogri MI, Bongarzone ER, Campagnoni AT: New insights on the biology of myelin basic protein gene: the neural-immune connection. J Neurosci Res 2000, 59(2):153-159.

21. Strand T, Alling C, Karlsson B, Karlsson I, Winblad B: Brain and plasma proteins in spinal fluid as markers for brain damage and severity of stroke. Stroke 1984, 15(1):138-144.

22. Ye B, Chen YY, Xie W: Clinical analyze of minimal Invasive treatment for adult gluteus contracture. Chin J General Practice 2010, 8(4):413-414.

23. Zhao $H$, Zhang $Y B$, Wang DX, Wang SP: Experimental research on activation of oligodendrocyte progenitor cells and myelination in the focal cerebral ischemic rat brain. Journal of Apoplexy and Nervous Diseases 2012, 29(4):332-334.

24. Gregersen $\mathrm{R}$, Christensen $\mathrm{T}$, Lehrmann E, Diemer NH, Finsen B: Focal cerebral ischemia induces increased myelin basic protein and growth-associated protein- 43 gene transcription in peri-infarct areas in the rat brain. Exp Brain Res 2001, 138(3):384-392.
25. Qi YH, Liu G, Shen X, Xiao L, Zhang XX, Yang P, Zhu Y, Chen YZ: Thecorrelation between serum myelin basic protein contents in acute cerebral infarction and TOAST classification. Chin J General Practice 2012, 10(11):1672-1676.

26. Chen J, He GH, Zeng SB, Hu XX, Li H: The clinical value of serial determination of $\mathrm{S} 100 \mathrm{~B}$ and $\mathrm{MBP}$ in patients with acute cerebral infarction. Chin J Clin Lab Sci 2005, 23(2):145-146.

27. Wang LW, Tu YF, Huang CC, Ho CJ: JNK signaling is the shared pathway linking neuroinflammation, blood-brain barrier disruption, and oligodendroglial apoptosis in the white matter injury of the immature brain. J Neuroinflammation 2012, 9(1):175-191.

28. Editorial JNMCCMD: Traditional Chinese Medicine Dictionary (part II). Shanghai: Shanghai Science and Technology Press; 1996:1548-1550.

29. Li T, Liu JW, Zhang XD, Guo MC, Ji G: The neuroprotective effect of picroside II from hu-huang-lian against oxidative stress. Am J Chin Med 2007, 35(4):681-691.

30. Li P, Matsunaga K, Yamakuni T, Ohizumi Y: Picrosidesland II, selective enhancers of the mitogen-activated protein kinase-dependent signaling pathway in the action of neuritogenic substances on PC12D cells. Life Sci 2002, 71(15):1821-1835.

31. Guo $Y, X u X, L i Q, L i Z$, Du F: Anti-inflammation effects of picrosidell in cerebral ischemic injury rats. Behav Brain Funct 2010, 6:43-53.

32. $L i Q, L i Z, X u X Y$, Guo YL, Du F: Neuroprotective properties of picroside II in rat model of focal cerebral ischemia. Int J Mol Sci 2010, 11(11):4580-4590.

33. $L i Z, X u X Y$, Shen $W$, Guo $Y L$ : The interference of picrosidell on the expressions of NFKB and IKB following cerebral ischemia reperfusion injury in rats. Chin Phar Bull 2010, 26(1):52-55.

34. Li Q, Guo YL, Li Z, Xu XY: The interference of picroside II on the expressions of Caspase- 3 and PARP following cerebral ischemia reperfusion injury in rats. Chin Phar Bull 2010, 26(3):342-345.

35. Li Z, Li Q, Guo YL, Qin LH, Luan LJ: Intervention effect of picroside II in cerebral ischemic injury rats. Acta Anat $\operatorname{Sin} 2010,41(1): 9-12$.

36. Wu QJ, Zhao WY, Liu JM: Chronic vasogenic cerebral ischemic animal modeling. Chin J Cerebrovasc Dis (Electronic Edition) 2011, 5(3):216-223.

37. Márquez-Martín A, Jiménez-Altayó F, Dantas AP, Caracuel L, Planas AM, Vila E: Middle cerebral artery alterations in a rat chronic hypoperfusion model. J Appl Physiol 2012, 112(3):511-518.

doi:10.1186/1471-2202-15-25

Cite this article as: Zhao et al:: The neuroprotective effect of picroside II via regulating the expression of myelin basic protein after cerebral ischemia injury in rats. BMC Neuroscience 2014 15:25.

\section{Submit your next manuscript to BioMed Central and take full advantage of:}

- Convenient online submission

- Thorough peer review

- No space constraints or color figure charges

- Immediate publication on acceptance

- Inclusion in PubMed, CAS, Scopus and Google Scholar

- Research which is freely available for redistribution 